\title{
Effects of gluten and transglutaminase on microstructure, sensory characteristics and instrumental texture of oat bread
}

\author{
Marjatta Salmenkallio-Marttila, Katariina Roininen, Karin Autio and Liisa Lähteenmäki \\ VTT Biotechnology, PO Box 1500, FIN-02044 VTT, Finland, e-mail: marjatta.salmenkallio-marttila@vtt.fi
}

\begin{abstract}
Effects of added gluten and transglutaminase on microstructure, instrumental texture and sensory characteristics of bread baked with 51\% wholemeal oat flour were compared in order to determine how changes in the state of macromolecules - protein and starch - correlate with changes in sensory and instrumental structure. Light microscopy, instrumental texture profile analysis, and descriptive sensory analysis were used to analyse the test breads. Addition of gluten and transglutaminase affected the structure of the protein network and distribution of water between the protein and starch phases. The differences in microstructure were quantified by determining the areas of starch and protein in the micrographs by image analysis. Breads baked with added gluten and water were softer and less gummy than the oat and wheat reference breads in the texture profile analysis. Addition of transglutaminase made the breads harder and gummier than the breads baked without the added enzyme. In the descriptive sensory analysis breads baked with added gluten or added gluten and water were evaluated as more soft and springy than the reference oat bread. Sensory characteristics of bread texture correlated well with the texture and microstructure measured instrumentally.
\end{abstract}

Key words: baking, oat bread, microstructure, gluten, transglutaminase, descriptive sensory analysis

\section{Introduction}

Whole grains are important sources of dietary fiber and other compounds of interest in disease prevention (Slavin et al. 1999). A substantial amount of the soluble dietary fiber of whole grain oat is $\beta$-glucan (mixed linkage $(1 \rightarrow 3)(1 \rightarrow 4)$ - $\beta$ -
D-glucan), a cell wall polysaccharide that is one of the important physiologically active dietary fiber components (Wood 2001). In addition to $\beta$-glucan, oat contains other dietary fibers, vitamins, minerals, antioxidants, sterols and other bioactive compounds, and proteins high in lysine (Lásztity 1998, South et al. 1999). The dietary fiber complex with its antioxidants and other 
Vol. 13 (2004): 138-150.

phytochemicals may protect us from cardiovascular disease and some types of cancer (Thompson 1994, Jacobs et al. 1998a, b, Slavin et al. 2000). Consumers have also learned to link whole grain products and good health.

Whole grain oat can be used to improve the taste of bread, and imparts a pleasant nutty flavour. Most commercial oat breads contain only a small amount of oat, $5-15 \%$. Oat is usually used in baking as rolled oats. Only few reports have been published on oat flour in breadbaking (Zhang et al. 1998). Oat as well as other whole grain products rich in fiber generally have a detrimental effect on bread quality. Dilution of gluten and mechanical disruption of the gluten network by bran particles decrease loaf volume (Pomeranz et al. 1977, Gan et al. 1992). At least some of the negative effects of whole grain flour on gluten development can be compensated for by the use of added gluten or baking enzymes. Addition of gluten has been shown to improve the structure of mixed oat bread (Flander et al. 2002) and transglutaminase has been shown to strengthen the protein network in wheat, rye and triticale baking (Gerrard et al. 1998, Gräber 2000, Poza 2002). Adding oat to the recipe also retards bread staling. This probably is due to the fact that oat starch retrogrades slower than wheat starch, and to the higher water binding capacity of oat flours in comparison to wheat.

Traditional light microscopy is useful in studying food structure as it allows selective staining of different chemical components (Fulcher and Wong 1980, Autio and Salmenkallio-Marttila 2003). Cereal grains have a well-organised microstructure with cell walls, starch granules and protein matrix as the main elements. In milling, the grain is ground to flour, which includes small particles of starch and starchy endosperm and larger particles consisting of the tough bran layers. In the baking process water, enzymes and energy transform the material into bread, a spongy structure largely characterised by pores. The textural properties of bread are dependent on the size and distribution of the pores and properties of the gelatinized starch and protein network forming the walls of the pores. Character- isation of microstructure of products is a key element in the understanding of effects of ingredients and processing conditions on the structure. Visualisation of the structures may provide useful data about how microstructure influences product properties, desired or undesired.

The aim of the study was to analyse the effects of gluten and transglutaminase on microstructure, sensory and instrumentally measured texture of mixed oat-wheat bread and to determine how changes in the state of macromolecules - protein and starch - correlate with changes in sensory and instrumental structure.

\section{Material and methods}

\section{Baking}

Commercial whole grain oat flour (cv. Aarre; Helsingin Mylly Ltd, Helsinki, Finland) and white wheat flour (Pakkasjauho, Melia Ltd., Raisio, Finland) were used for baking. The oat flour contained $10.6 \%$ moisture, $17.3 \%$ db protein, $6.0 \% \mathrm{db} \beta$-glucan and $2.8 \% \mathrm{db}$ ash. The wheat flour contained $12.1 \%$ moisture, $14.3 \% \mathrm{db}$ protein, $1.0 \% \mathrm{db} \beta$-glucan and $0.8 \% \mathrm{db}$ ash. Protein was determined with Kjeldahl method ( $\mathrm{N} \mathrm{x}$ 5.7), $\beta$-glucan with enzymatic Megazyme method (McCleary and Codd 1991) and ash with standard method AACC 08-9. Fresh compressed baker's yeast (Suomen Hiiva Ltd, Lahti, Finland), vital wheat gluten (Raisio Grain Starch Ltd, Raisio, Finland) and transglutaminase Activa WM containing $1 \%$ active enzyme and $99 \%$ maltodextrin (Ajinomoto, Japan) were used for baking. Transglutaminase activity of the preparate was 114 units/g. Transglutaminase was determined using N-carbobenzoxy-glutamyl-glycine and hydroxylamine as substrate according to Folk and Cole (1966).

Five different recipes with different water, transglutaminase, and gluten contents were used to bake oat breads (Table 1). The flour used in baking was whole grain oat $(51 \%)$ and wheat 


\section{Salmenkallio-Marttila, M. et al. Effects of gluten and transglutaminase on oat bread}

Table 1. Ingredient variables in the oat bread recipes (\% of flour).

\begin{tabular}{lccccc}
\hline & 1 & 2 & 3 & 4 & 5 \\
\hline Water & 70 & 79 & 100 & 70 & 100 \\
Gluten & - & 6 & 6 & - & 6 \\
Transglutaminase & - & - & - & 0.4 & 0.4 \\
\hline
\end{tabular}

(49\%). The recipe for the control oat bread was (g) oat flour (1020), wheat flour (980), yeast (60), salt (40), sugar (60), fat (60) and water (1400). The doughs were mixed with a Diosna spiral mixer for $12 \mathrm{~min}$. After a floor time of 12 $\min$ at $23^{\circ} \mathrm{C}$, the dough was divided into $400 \mathrm{~g}$ loaves. The loaves were proofed in pans $(60 \mathrm{~min}$ at $37^{\circ} \mathrm{C}, 80 \% \mathrm{rh}$ ) and baked at $195^{\circ} \mathrm{C}$ for $30 \mathrm{~min}$. Bread volume was determined by rapeseed displacement.

\section{Crumb firmness and elasticity measurements}

Crumb firmness was measured on baking day as maximum compression force ( $40 \%$ compression, AACC 1998, method 74-09) using the Texture Profile Analysis (TPA) test (TA-XT2 Texture Analyser, Stable Micro Systems, Godalming, UK).

\section{Rheological measurements}

In the swelling curve test (Drews 1971) the viscosity of flour-buffer suspension (120 g flour in $410 \mathrm{ml}$ phosphate-citrate buffer $\mathrm{pH}$ 5) was measured in a Brabender viscograph (Brabender viscograph-E, Brabender OHG, Duisburg, Germany) with a $500 \mathrm{cmg}$ measuring cartridge. The suspension was heated from $30^{\circ} \mathrm{C}$ to $42^{\circ} \mathrm{C}$ with a temperature gradient of $1.5^{\circ} \mathrm{C} \mathrm{min}^{-1}$, and then kept at $42^{\circ} \mathrm{C}$ for $30 \mathrm{~min}$. The initial viscosity at $30^{\circ} \mathrm{C}$, viscosity at $42^{\circ} \mathrm{C}$ and viscosity at $42^{\circ} \mathrm{C}$ after 30 min were recorded in Brabender units.

Doughs were prepared without yeast to determine the storage modulus, loss modulus and phase angle during heating (Bohlin VOR rheometer in oscillatory mode, ReoLogica Instruments AB, Lund, Sweden). The rheometer was equipped with a high temperature cell and a plate-plate measuring geometry (PP25HT). The gap between plates was $1.5 \mathrm{~mm}$, the strain $10^{-3}$ and the frequency $1 \mathrm{~Hz}$. The dough was allowed to rest for $5 \mathrm{~min}$ at room temperature after mixing. A $1.05 \mathrm{~g}$ piece of dough was placed on the lower plate, the upper plate was lowered to the right position and silicone oil was applied on the edges of the dough piece to prevent drying. The measurement was started at $30^{\circ} \mathrm{C}$ and the temperature was raised to about $100^{\circ} \mathrm{C}$ at a rate of $2^{\circ} \mathrm{C} \mathrm{min}-1$. Each curve is the average of two runs.

\section{Microscopy and image analysis}

For microstructure analysis 4-6 pieces were taken from two loaves originating from separate test bakings. Pieces of bread crumb $(0.5 \mathrm{~cm})$ were taken from the middle of the loaf, embedded in $1 \%$ agar, fixed in $1 \%$ glutaraldehyde in $0.1 \mathrm{M}$ phosphate buffer, $\mathrm{pH}$ 7.0, dehydrated with ethanol and embedded in hydroxyethyl methylacrylate as recommended by the manufacturer (Historesin, Leica, Heidelberg, Germany). Sections were cut $4 \mathrm{~mm}$ thick in a Leica rotary microtome HM 355 (Heidelberg, Germany) using a steel knife. The sections were transferred onto glass slides and stained with Light Green and Lugol's iodine solution (Fulcher and Wong 1980, Wood et al. 1983, Parkkonen et al. 1994). Protein was stained with aqueous $0.1 \%$ (w/v) Light Green for 1 min (Gurr, BDH Ltd, Poole, UK) and starch with 1:10 diluted Lugol's iodine solution $\left(\mathrm{I}_{2} 0.33 \%\right.$, w/v and KI $0.67 \%$, w/v). Light Green stains protein green ( $\mathrm{pH} 4.5)$. Iodine stains the amylose component of starch blue and amylopectin brown. Most starch appears dark blue because the amylopectin masks the amylose.

The samples were examined with an Olympus BX-50 microscope (Tokyo, Japan). Micrographs were obtained with a SensiCam CCD camera (PCO, Kelheim, Germany) and analysed with the AnalySIS 3.0 image analysis program 
(Soft Imaging System, Münster, Germany). Forty images (10x) of each bread were analysed; the area analysed was $1 \mathrm{~mm}^{2}$ per bread corresponding to more than 1000 starch granules (Salmenkallio-Marttila et al. 2004). The photographs shown were chosen to represent the samples.

\section{Sensory perception of texture}

Ten trained assessors evaluated bread samples in the sensory evaluation laboratory of VTT Biotechnology using a computerized data-collection program (CSA Computerized Sensory Analysis System, Compusense Inc., Guelph, Canada Compusense 5, version 4.2). Each assessor evaluated all six samples in the morning and in the afternoon. This procedure was repeated once with one day old samples. The samples were marked with three-digit random codes, and presented in random order. One training evaluation was conducted before actual evaluations. The assessors received feedback from their training evaluation.

The assessors evaluated three visual attributes and seven texture attributes of the samples on a 10 -unit line scale. Visual attributes evaluated were volume, pore size and uniformity of pore size. Texture attributes of mouthfeel of the crumb were moistness, softness, density, crumbliness and springiness of crumb. In addition, crispness and hardness of crust was assessed but they are not reported here as all the other measurements were made from inner parts of bread and they are not comparable with crust characteristics.

\section{Statistical analysis}

The baking results are means of the analyses of four replicate breads. Each recipe was baked twice. The differences in each texture attribute were studied using two-way analysis of variance. The differences in sensory quality of the samples were tested with 3-way ANOVA using sample (6), replicate (1. or 2. assessment) and time (Day 0 or Day 1) as independent variables and ratings of each sensory attribute as dependent variables. The differences in means among samples were further tested with Tukey's HSD-test. Correlations between variables are calculated as Pearson's product moment correlations.

\section{Results}

\section{Rheological properties of the doughs}

Swelling curve data from the test flours shows the initial viscosity of flour-water suspension at $30^{\circ} \mathrm{C}$, viscosity at $42^{\circ} \mathrm{C}$, and viscosity after 30 min at $42^{\circ} \mathrm{C}$ (Table 2). Swelling curves are commonly used for rye quality control. The initial viscosity reflects the amount of water-binding material present in the flour. The viscosity usually decreases during the holding time. The rate of decrease and final viscosity are influenced by the amount, solubility and properties of cell-wall polysaccharides and by the activity of cell-wall degrading enzymes. Oat grains are usually heat-

Table 2. Swelling curve data for the flours, viscosities as Brabender units.

\begin{tabular}{lccrr}
\hline Sample & Initial viscosity & Viscosity at $42^{\circ} \mathrm{C}$ & Final viscosity & Difference \\
& A & B & C & $1000 \times(\operatorname{logB}-\log$ C $)$ \\
\hline Oat & $40 \pm 0$ & $150 \pm 1$ & $750 \pm 1$ & $-699 \pm 0$ \\
Wheat & $25 \pm 1$ & $20 \pm 1$ & $15 \pm 1$ & $125 \pm 0$ \\
Oat 51\% + Wheat 49\% & $30 \pm 1$ & $30 \pm 1$ & $30 \pm 1$ & $0 \pm 0$ \\
\hline
\end{tabular}


treated before milling and exhibit only very low enzyme activities. Both the high content of water-binding material and low amount of cell-wall degrading enzymes are evident from the high viscosities of the oat flour. The viscosities of wheat flour and the mixture of oat and wheat were much lower indicating the activity of enzymes originating from wheat flour.

Rheological measurements were made during a temperature sweep from $30^{\circ} \mathrm{C}$ to $100^{\circ} \mathrm{C}$, to mimic the initial part of the baking process. At $30^{\circ} \mathrm{C}$ the storage modulus, $\mathrm{G}$ ', was lower for the doughs containing gluten (Recipes 2, 3 and 5, Fig. 1) than for the doughs with no added gluten (Recipes 1 and 4). G' started to increase at around $50^{\circ} \mathrm{C}$ and reached a maximum value at about $72^{\circ} \mathrm{C}$. The increase in $\mathrm{G}^{\prime}$ was shifted to slightly higher temperatures for the doughs containing added gluten. The two doughs with the highest water content reached the maximum value at a lower temperature than the ones with less water. The maximum values were highest for doughs with the lowest water content (4 and 1). Addition of transglutaminase increased the maximum G' value (Doughs 1 and 4, Doughs 3 and 5) but did not affect the gelatinization temperature.

\section{Microstructure of the test breads}

Microstructure of the crumb of $51 \%$ wholemeal oat bread (containing 0 or $6 \%$ added gluten) was examined by bright field microscopy and compared to that of white bread (Fig. 2 and 3). Wholemeal crumb differed markedly from that of white bread, being coarse and consisting of a discontinuous protein matrix. The commercial white wheat bread had a looser structure (Fig. $2 \mathrm{f}$ and $3 \mathrm{f})$ : the starch granules were least swollen in this sample and the protein network was fine, a thin continuous protein matrix separated the starch granules from each other. The oat breads looked more dense because of the more swollen starch granules (Fig. 2a-e and 3a-e). In the reference oat bread (Fig. 2a and 3a, Recipe 1) starch was the least swollen in comparison to the other oat breads and the protein network was continuous and fine-stranded. In the oat bread baked with added gluten (Fig. 2b and 3b, Recipe 2) starch was slightly more swollen than in the reference oat bread and the protein network was uniform but coarser. In the oat bread baked with added gluten and water (Fig. $2 c$ and $3 c$, Recipe 3), starch granules were highly swollen
Fig. 1. Effect of heating on storage modulus of test doughs. $\operatorname{tg}=$ transglutaminase.

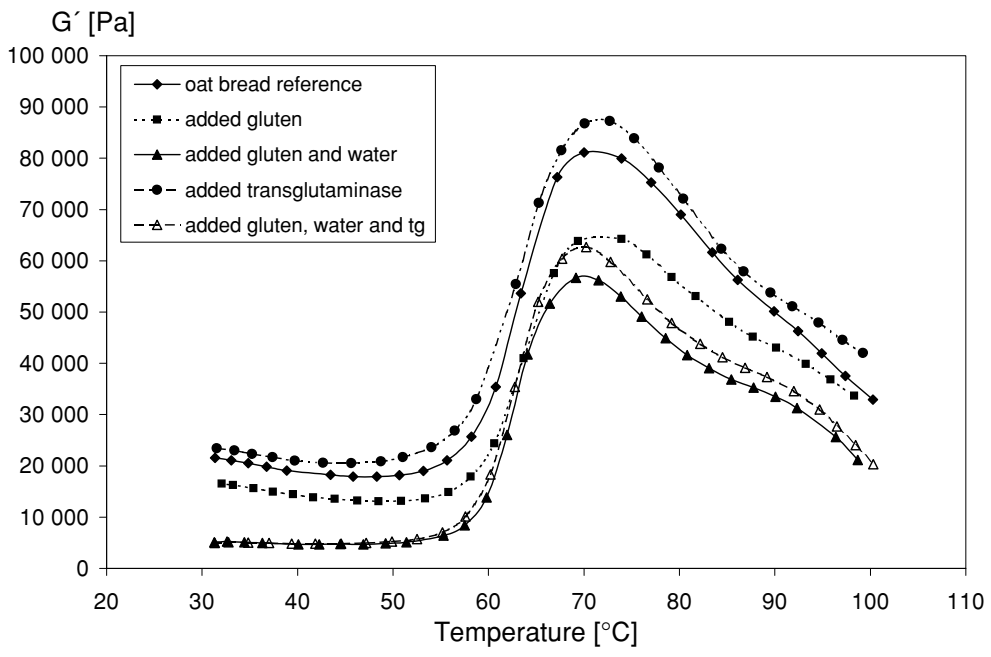



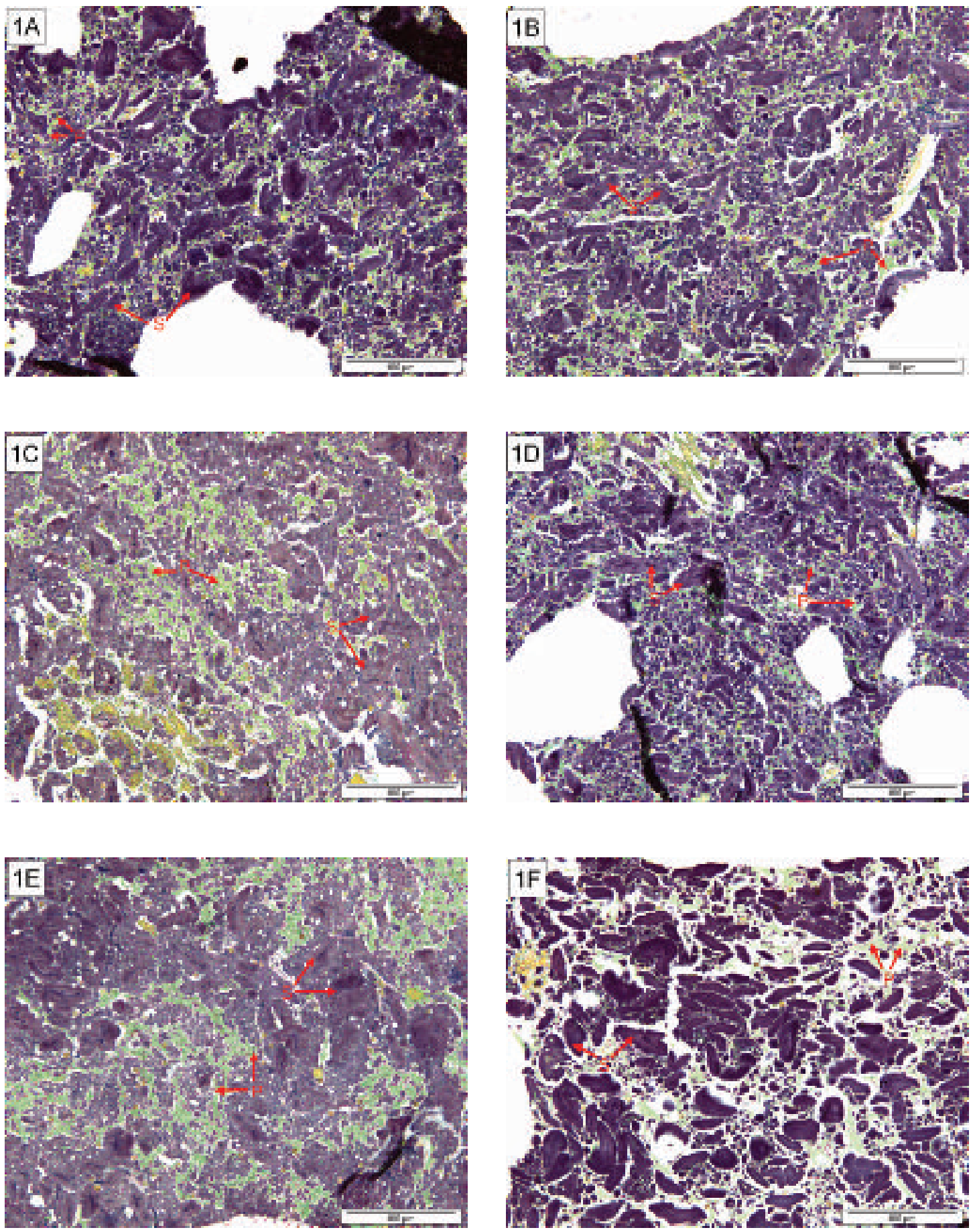

Fig. 2. Microstructure of the bread samples: a) oat bread reference, b) oat bread with added gluten, c) oat bread with added water and gluten, d) oat bread with added transglutaminase, e) oat bread with added water, gluten and transglutaminase and f) white wheat bread. $\mathrm{P}=$ protein, $\mathrm{S}=$ starch. 
Salmenkallio-Marttila, M. et al. Effects of gluten and transglutaminase on oat bread
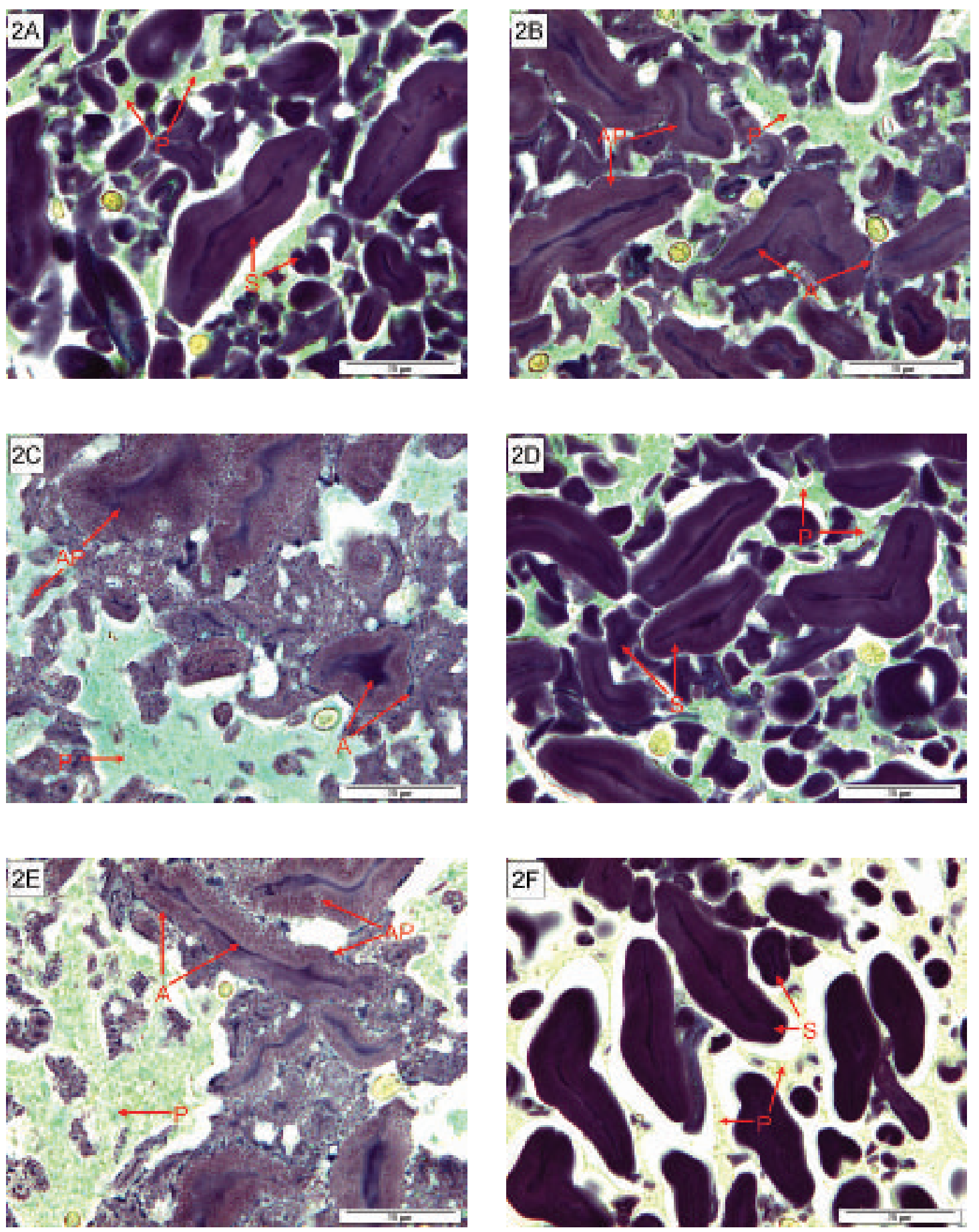

Fig. 3. Microstructure of the bread samples: a) oat bread reference, b) oat bread with added gluten, c) oat bread with added water and gluten, d) oat bread with added transglutaminase, e) oat bread with added water, gluten and transglutaminase and f) white wheat bread. $\mathrm{P}=$ protein, $\mathrm{S}=$ starch, $\mathrm{A}=$ amylose, $\mathrm{AP}=$ amylopectin. 
and contorted. Amylose had separated from amylopectin and was visible in the central groove and surrounding the granules. The protein network was coarse and discontinuous. In the oat bread baked with added transglutaminase (Fig. $2 \mathrm{~d}$ and $3 \mathrm{~d}$, Recipe 4) starch granules were only slightly swollen like in the reference bread, the protein network was fairly even but more discontinuous than in the reference bread (Fig. 2a and $3 \mathrm{a}$ ). In the oat bread baked with added gluten, transglutaminase and water (Fig. 2e and 3e, Recipe 5) starch was highly swollen and contorted and amylose had separated from amylopectin being visible in the central groove and surrounding the granules. The protein network was discontinuous and coarse, protein and starch occurred in large separate patches.

To quantify the differences in microstructure, the areas of starch and protein in the micrographs were determined by image analysis (Fig. 4). The area of starch was smallest in the white wheat bread used as reference and in the two oat breads baked with high water content and added gluten (Recipes 3 and 5). The area of protein was smallest in the reference oat bread (Recipe 1) and in the white wheat bread; the two oat breads baked with high water content and added gluten had the largest area of protein.

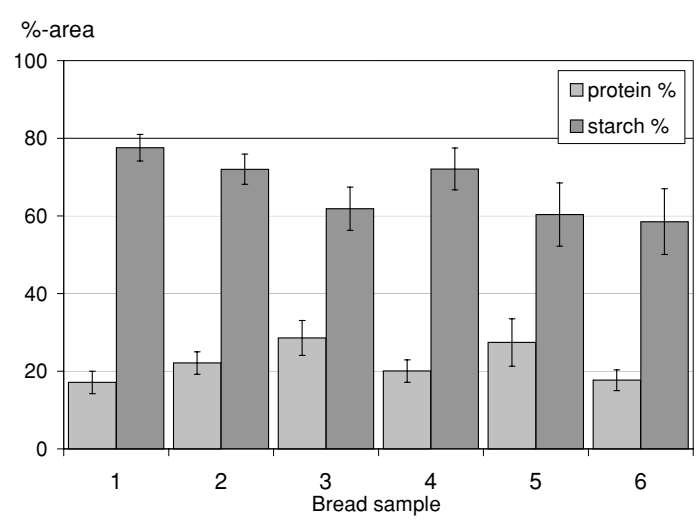

Fig. 4. Area (\%) of starch and protein in the micrograps prepared from the oat bread samples 1-5 and the commercial white wheat bread.

\section{Instrumental structure of the test breads}

The specific volume of the oat breads ranged from $1.5 \mathrm{ml} \mathrm{g}^{-1}$ to $2.8 \mathrm{ml} \mathrm{g}^{-1}$, while the specific volume of the white wheat bread was $3.6 \mathrm{ml} \mathrm{g}^{-1}$ (Table 3). The bread baked with added transglutaminase (Recipe 4) had the lowest volume and was also hardest in the TPA-analysis (Table 3 ). Very soft dough ( $100 \%$ of water) with added gluten (Recipe 3 ) gave the best volume and softest texture. The oat breads baked with very soft dough (Recipes 3 and 5) were softer than the commercial white wheat bread even though their specific volume was lower. The two recipes with lowest level of water addition gave bread with highest scores for gumminess and chewiness.

\section{Sensory perception of texture}

The textures of the breads were analysed using descriptive sensory analysis (Fig. 5). The differences between samples were statistically significant in all attributes. The softness of bread samples decreased slightly (7.4 vs. 7.0, P > 0.05), but the changes were not significantly different between samples. Overall, the samples also became more crumbly in one day after baking (2.5 vs. $3.4, \mathrm{P}=0.001$ ), the one day old samples disintegrated more easily in the mouth than fresh bread. As these changes did not differ among samples the profile is represented as the mean of all four sensory ratings made of each sample. All differences between samples reported here are significant (Tukey's HSD, $\mathrm{P}<0.05$ ). In the sensory analysis Oat breads 3 and 5 baked with $100 \%$ water and added gluten were rated as soft as the white wheat bread. They were rated less dense than the white wheat bread, but more springy and moist. The reference oat bread (Recipe 1) and the bread baked with added transglutaminase (Recipe 4) had almost identical profiles; both were rated as more dense than the other breads and less moist than Samples 3 and 5 with added water.

Sensory characteristics of bread texture correlated with the instrumentally measured texture 
Salmenkallio-Marttila, M. et al. Effects of gluten and transglutaminase on oat bread

Table 3. Specific volume and texture profile analysis of the five oat breads (Samples 1-5) and commercial wheat bread (Sample 6).

\begin{tabular}{lcccccc}
\hline & $\begin{array}{c}1 \\
\text { Reference }\end{array}$ & $\begin{array}{c}2 \\
\text { Added gluten }\end{array}$ & $\begin{array}{c}3 \\
\text { Added water } \\
\text { and gluten }\end{array}$ & $\begin{array}{c}4 \\
\text { Added } \\
\text { transglutaminase }\end{array}$ & $\begin{array}{c}5 \\
\text { Added water, } \\
\text { gluten and } \\
\text { transglutaminase }\end{array}$ & $\begin{array}{c}\text { Wheat bread } \\
\text { reference }\end{array}$ \\
\hline Specific volume, g ml ${ }^{-1}$ & 1.7 & 2.4 & 2.8 & 1.5 & 2.7 & 3.6 \\
Hardness, g & $904 \pm 61$ & $512 \pm 32$ & $170 \pm 16$ & $1271 \pm 116$ & $175 \pm 9$ & $308 \pm 39$ \\
Cohesiveness & $0.543 \pm 0.009$ & $0.574 \pm 0.006$ & $0.588 \pm 0.006$ & $0.526 \pm 0.014$ & $0.596 \pm 0.011$ & $0.556 \pm 0.015$ \\
Gumminess & $490 \pm 29$ & $294 \pm 17$ & $100 \pm 9$ & $667 \pm 49$ & $104 \pm 5$ & $171 \pm 16$ \\
Chewiness & $471 \pm 33$ & $280 \pm 24$ & $94 \pm 13$ & $571 \pm 88$ & $96 \pm 13$ & $155 \pm 16$ \\
\hline
\end{tabular}

and microstructure of the bread samples (Table 4). Sensory softness decreased with increasing instrumentally measured hardness of the samples $\left(\mathrm{r}=-0.97^{* *}\right)$. Large area of protein in the micrographs corresponded to low sensory density and low sensory moistness values in the bread samples $(\mathrm{r}=-0.92 * *$ and $\mathrm{r}=-0.96 * *)$. The large percent area of protein in the micrographs corresponded also to high instrumental cohesiveness $(\mathrm{r}=0.83 *)$. Samples with large area of starch in the micrographs had low sensory softness $\left(\mathrm{r}=-0.90^{*}\right)$, low specific volume of the loaf $(\mathrm{r}=-0.87 *)$ and high instrumental chewiness $\left(\mathrm{r}=0.85^{*}\right)$.

\section{Discussion}

Partial replacement of wheat flour by oat flour affects bread quality (Zhang et al. 1998). Gas retention of oat flour dough is poor in comparison to wheat flour dough, as oat does not con-

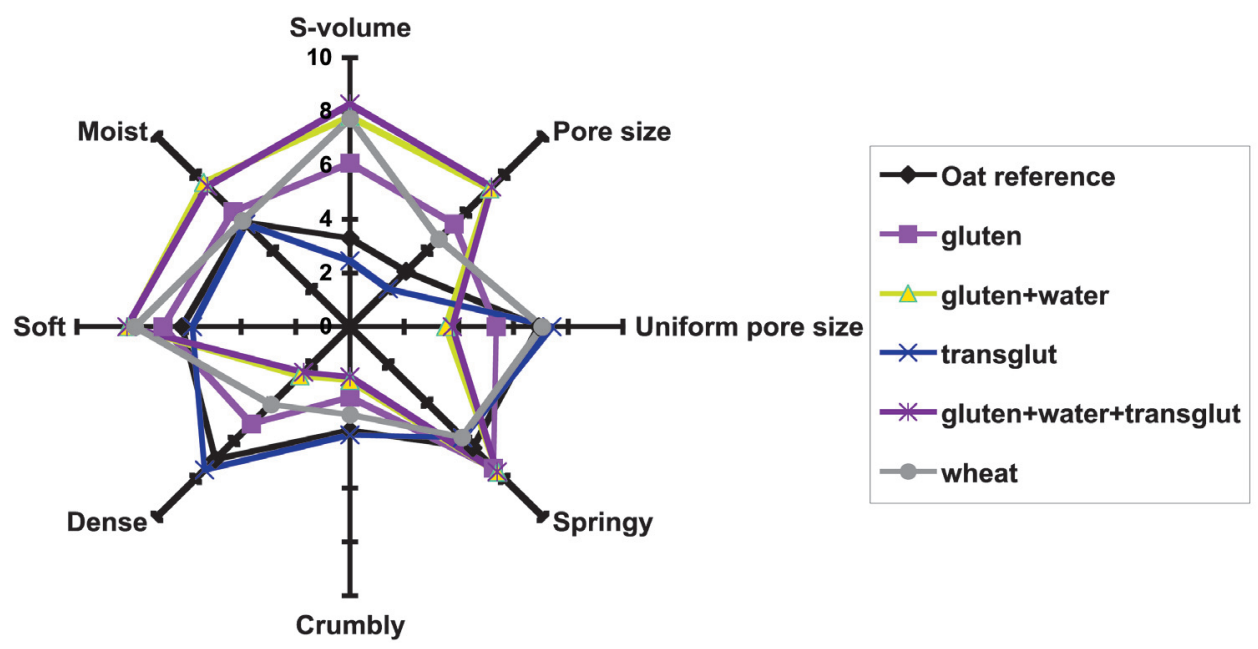

Fig. 5. Descriptive sensory analysis profile of the test breads. 
Vol. 13 (2004): 138-150.

Table 4. Correlations of sensory characteristics $(\mathrm{S})$, microstructure (IA = image analysis) and instrumentally measured texture (I).

\begin{tabular}{|c|c|c|c|c|c|c|c|}
\hline & IA-prot & IA-starch & I-hardness & I-cohesive & I-gummy & I-chewy & I-vol \\
\hline S-volume & 0.570 & $-0.874 *$ & $-0.977 * *$ & $0.848 *$ & $-0.980 * *$ & $-0.989 * *$ & $0.911 *$ \\
\hline S-pore size & 0.789 & -0.747 & $-0.962 * *$ & $0.970 * *$ & $-0.961 * *$ & $-0.965 * *$ & 0.723 \\
\hline S-uniform pore size & $-0.915 *$ & 0.525 & $0.826^{*}$ & $-0.973 * *$ & $0.822 *$ & $0.820 *$ & -0.435 \\
\hline S-springy & 0.750 & 0.097 & -0.569 & $0.839 *$ & -0.551 & -0.526 & 0.105 \\
\hline S-crumbly & $0.898 *$ & 0.615 & $0.845^{*}$ & $-0.982 * *$ & $0.844^{*}$ & $0.851 *$ & -0.495 \\
\hline S-dense & $-0.920 * *$ & 0.667 & $0.862 *$ & $-0.968 * *$ & $0.865^{*}$ & $0.874^{*}$ & -0.519 \\
\hline S-soft & 0.548 & $-0.903 *$ & $-0.972 * *$ & 0.811 & $-0.978 * *$ & $-0.987 * *$ & $0.928 * *$ \\
\hline S-moist & $0.958 * *$ & -0.581 & -0.777 & $0.920 * *$ & -0.781 & -0.791 & 0.391 \\
\hline
\end{tabular}

** Correlation is significant at the 0.01 level (2-tailed).

* Correlation is significant at the 0.05 level (2-tailed).

tain the gluten-forming proteins that are essential in forming the structure of wheat bread. Instead, other flour components such as starch and the non-starch polysaccharides affect dough properties and bread structure formation in oat baking. Oat contains a large amount of $\beta$-glucan, a soluble, highly viscous cell wall polysaccharide. $\beta$-Glucan makes the dough sticky and affects gelatinization of starch because of its high water-binding capacity. The use of wholemeal oat flour in baking complicates the picture even more, as bran particles have been shown to hinder mechanically gluten structure formation (Gan et al. 1989, 1992). In all of these characteristics, oat baking resembles rye baking. Rye breads are significantly harder than wheat breads. The large number of bran particles and the low porosity contribute to the hardness of rye breads, as is probably also the case with other whole grain breads.

Changes in dough structure during baking can be studied by measuring the storage modulus (G') during heating. Dough viscosity increases markedly above $60^{\circ} \mathrm{C}$ because of starch gelatinization, starch granules swell and amylose exudes from them. The temperature for maximum G' and also the loaf volumes were higher for the breads containing added gluten (Fig. 1, Recipes $2,3,5)$ than that for the other oat breads. The relationship between gelatinization temperature and baking quality is still a matter of speculation (Bloksma 1990). In rye baking the best quality of bread is obtained when the rise in G' during heating is slow and the maximum value not too high and obtained at as high a temperature as possible (late during the baking process, Repeckiene et al. 2001).

Transglutaminase improved elasticity of the $51 \%$ oat dough. The enzyme catalyses protein cross-linking and has been shown to induce the formation of high molecular weight polymers from gluten (Larré et al. 1999). The superimposition of covalent bonds to the gluten network stabilised it against temperature. Hydrated glutenin is a tough, elastic material, hydrated gliadin is a viscous liquid. Formation of covalent crosslinks between the gluten molecules increases the elasticity of the dough.

The most noticeable structural change that occurs at the microstructural level during the baking process is starch gelatinization. The extent of starch swelling and leaching of amylose differ greatly in typical wheat and rye breads (Autio et al. 1997). In wheat bread, amylose is mainly located inside the granule, and the starch granules are much less swollen than in rye bread. In rye breads, partly due to the higher water content and partly to the presence of a-amylase, starch granules are more swollen than in wheat bread, part of the amylose has leached out from 


\section{Salmenkallio-Marttila, M. et al. Effects of gluten and transglutaminase on oat bread}

the starch granules, and amylose and amylopectin are separated from each other. At higher water content, the starch granules are more swollen and more amylose leaches out. This has also been shown here to be the case with oat bread.

Starch granules of wheat are of two sizes, a third size group of very small starch granules has also been suggested (less than $5 \mu \mathrm{m}$ in diameter, Bechtel et al. 1990). The large discshaped granules are $25-50 \mu \mathrm{m}$ in diameter and the small spherical ones have a diameter of about $9 \mu \mathrm{m}$ (Bechtel et al. 1990). Oat starch occurs in the grain as a compound granule composed of several individual starch granules in many ways similar to rice starch. The size of the aggregates ranges from 20 to $150 \mu \mathrm{m}$ in diameter, and the individual granules are $2-15 \mu \mathrm{m}$ across. Oat starch granules are rather fragile when swollen and gelatinized, and amylose and amylopectin leach from the granules during pasting (Doublier et al. 1987, Autio 1990, Virtanen et al.1993). The aggregate structure of oat starch is still visible in baked bread containing oat starch. In microscopic analysis of the bread samples large differences in the structure of starch and protein network were observed. The differences in starch gelatinization can mainly be attributed to differences in the amount of water in the dough. In breads baked with high water addition the starch polymers amylose and amylopectin were phase separate and accumulation of amylose was observed in the centre of starch granules. The extent of starch swelling and leaching of amylose differ greatly in different types of breads. In wheat bread amylose is mainly located inside the starch granules, and the granules are much less swollen than in oat and rye breads. In oat breads, due to the high water content, starch granules were highly swollen, part of the amylose had leached out from the granules, and amylose and amylopectin were separated from each other.

The level of gluten addition was adjusted to compensate for the dilution of gluten caused by the use of whole grain oat flour. To improve the bread structure, addition of gluten was accompanied by additional water. In the sensory analysis the oat breads baked with $100 \%$ water and added gluten were rated as soft as the white wheat bread. They were rated less dense than the white wheat bread, but more springy and moist. The appearance of starch granules and the pattern of starch gelatinization were also affected by the addition of water and gluten. In the breads baked with added water starch granules were more swollen and distorted and amylose had leached out of the granules. Amylose was seen in the central groove and as a distinct blue layer surrounding the starch granules.

Effect of transglutaminase on bread structure was seen in the micrographs as a more compact, coarse and discontinuous protein network. Transglutaminase is best known for its use in meat, fish and dairy products. Transglutamine forms covalent links between amino acids thus stabilising the protein network in food products. In baking the use of transglutaminase is relatively new (Gerrard et al. 1998). During breadmaking the enzyme cross-links gluten proteins and by strengthening the gluten can improve the rheological properties of the dough. Transglutaminase has been shown to be especially useful when baking with weak flour (Gerrard et al. 1998).

Sensory characteristics of bread texture correlated with the instrumentally measured texture and microstructure of the bread samples. Sensory softness decreased with increasing instrumentally measured hardness of bread. Samples with large area of starch in the micrographs had low sensory softness, low specific volume of the loaf and high instrumental chewiness. The area of starch was smallest in the white wheat bread used as reference and in the two oat breads baked with high water content and added gluten. The two oat breads with the smallest area of starch were baked with added gluten, had low instrumental hardness and also had the largest area of protein in the micrographs. Large area of protein in the micrographs corresponded to low sensory density and low sensory moistness values in the bread samples.

In conclusion, the differences in loaf volume, instrumental hardness and starch gelatinization in the oat bread samples were mainly due to differences in the amount of water in the dough. 
Vol. 13 (2004): 138-150.

Sensory characteristics of bread texture correlated well with the instrumentally measured texture and microstructure of the samples. These results demonstrate that microstructure has an important role in perceived mouthfeel and the novel approach in combining these two measures can be used to improve our understanding of the links between these two measurements.

Acknowledgements. This study was part of the VTT research program Tailored technologies for future foods. The skilful technical assistance of Arja Viljamaa, Leila Kostamo and Ritva Heinonen is acknowledged.

\section{References}

AACC 1998. Approved methods of the AACC. 9th ed. Method 74-09, approved November 1995, reviewed October 1996. American Association of Cereal Chemists: St. Paul, MN.

Autio, K. 1990. Rheological and microstructural changes of oat and barley starches during heating and cooling. Food Structure 9: 297-304.

Autio, K., Parkkonen, T. \& Fabritius, M. 1997. Observing structural differences in wheat and rye breads. Cereal Foods World 42: 702-705.

Autio, K. \& Salmenkallio-Marttila, M. 2003. Understanding microstructural changes in biopolymers using light and electron microscopy. In: Kaletunc, G. \& Breslauer, K.J. (eds.). Characterization of cereals and flours. New York, USA: Marcel Dekker Inc. p. 387-408.

Bechtel, D.B., Zayas, I., Kaleikau, L. \& Pomeranz, Y. 1990. Size-distribution of wheat starch granules during endosperm development. Cereal Chemistry 67: 59-63.

Bloksma, A.H. 1990. Rheology of the breadmaking process. Cereal Foods World 35: 228-236.

Doublier, J.-L., Paton, D. \& Llamas, G.A. 1987. Rheological investigation of oat starch pastes. Cereal Chemistry 64: 21-26.

Drews, E. 1971. Quellenkurven von Roggenmahlprodukten. Mühle und Mischfuttertechnik 49: 723-724.

Flander, L., Salmenkallio-Marttila, M., Suortti, T. \& Autio, K. 2002. Baking a functional oat bread. In: $A A C C$ Annual Meeting. Montreal, Canada, 13-17 Oct 2002. American Association of Cereal Chemistry. p. 138139.

Folk, J.E. \& Cole, P.W. 1966. Mechanism of action of guinea pig liver transglutaminase. Journal of Biological Chemistry 241: 5518-5525.

Fulcher, R.G. \& Wong, S.J. 1980. Inside cereals - A fluorescence microchemical view. In: Inglett, G.E. \& Munck, L. (eds.). Cereals for food and beverages. New York, USA: Academic Press. p. 1-26.
Gan, Z., Ellis, P.R., Vaughan, J.G. \& Galliard, T. 1989. Some effects of non-endosperm components of wheat and of added gluten on wholemeal bread microstructure. Journal of Cereal Science 10: 81-91.

Gan, Z., Galliard, T., Ellis, P.R., Angold, R.E. \& Vaughan, J.G. 1992. Effect of the outer bran layers on the loaf volume of wheat bread. Journal of Cereal Science 15: 151-163.

Gerrard, J.A., Fayle, S.E., Wilson A.J., Newberry, M.P., Ross, M. \& Kavale, S. 1998. Dough properties and crumb strength of white pan bread as affected by microbial transglutaminase. Journal of Food Science 63: 472-475.

Gräber, S. 2000. Neue Möglichkeiten zur Beeinflussung der Teigeigenschaften bei Roggen und Triticale. Getreide Mehl und Brot 54: 160-164.

Jacobs, D.R., Jr., Marquart, L., Slavin, J. \& Kushi, L.H. 1998a. Whole-grain intake and cancer: an expanded review and meta-analysis. Nutrition and Cancer 30 : 85-96.

Jacobs, D.R., Jr., Meyer, K.A., Kushi, L.H. \& Folsom, A.R. $1998 \mathrm{~b}$. Whole-grain intake may reduce the risk of ischemic heart disease death in postmenopausal women: the lowa Women's Health Study. American Journal of Clinical Nutrition 68: 248-257.

Larré, C., Denery-Papini, S., Popineau, Y., Deshayes, G., Desserme, C. \& Lefebvre, J. 1999. Biochemical analysis and rheological properties of gluten modified by transglutaminase. Cereal Chemistry 77: 121-127.

Lásztity, R. 1998. Oat grain - a wonderful reservoir of natural nutrients and biologically active substances. Food Reviews International 14: 99-119.

McCleary, B. \& Codd, R. 1991. Measurement of $(1 \rightarrow 3),(1 \rightarrow 4)-\beta-D$-glucan in barley and oats: a streamlined enzymic procedure. Journal of the Science of Food and Agriculture 55: 303-312.

Parkkonen, T., Härkönen, H. \& Autio, K. 1994. The effect of baking on microstructure of rye cell walls and proteins. Cereal Chemistry 71: 58-63.

Pomeranz, Y., Shogren, M.D., Finney, K.F. \& Bechtel, D.B. 1977. Fiber in breadmaking - Effects on functional properties. Cereal Chemistry 54: 25-41.

Poza, D.O. 2002. Transglutaminase in baking applications. Cereal Foods World 47: 93-95. Repeckiene, A., Eliasson, A.-C., Juodeikiene, G. \& Gunnarsson, E. 2001. Predicting baking performance from rheological and adhesive properties of rye meal suspensions during heating. Cereal Chemistry 78: 193-199.

Salmenkallio-Marttila, M., Roininen, K., Lindgren, T., Rousu, J., Autio, K. \& Lähteenmäki, L. 2004. Applying machine learning methods in studying relationships between mouthfeel and microstructure in oat bread. Journal of Texture Studies 35 (in press).

Slavin, J., Marquart, L. \& Jacobs, D., Jr. 2000. Consumption of whole-grain foods and decreased risk of cancer: proposed mechanisms. Cereal Foods World 45: 54-58.

Slavin, J., Martini, M.C., Jacobs, D.R., Jr. \& Marquart, L. 1999. Plausible mechanisms for the protectiveness of whole grains. American Journal of Clinical Nutrition 70(suppl): 459S-463S.

South, J.B., Townsley, C., Atkin, D., Alvey, M., Laverick, 
Salmenkallio-Marttila, M. et al. Effects of gluten and transglutaminase on oat bread

R.M., Webb, C., Campbell, G., Wang, R., Gray, D., Hill, S., Auerbach, R., Jumel, C., Barclay, F., Sriburi, P., Forge, C., Rogers, L., Kelly, L., Livermore, M., Smith, I. \& Jee, M. 1999. Sourcing added value food ingredients from home-grown oats. HGCA project report No. 194. London, UK: HGCA. p. 238.

Thompson, L.U. 1994. Antioxidants and hormone-mediated health benefits of whole grains. Critical Reviews in Food Science and Nutrition 34: 473-497.

Virtanen, T., Autio, K., Suortti, T. \& Poutanen, K. 1993. Heat-induced changes in native and acid-modified oat starch pastes. Journal of Cereal Science 17: 137145.
Wood, P.J. 2001. Cereal b-glucans: structure, properties and health claims. In: McCleary, B.V. \& Prosky, L. (eds.). Advanced dietary fibre technology. Oxford, UK: Blackwell Science Co. p. 315-318.

Wood, P.J., Fulcher, R.G. \& Stone, B.A. 1983. Studies on the specificity of interaction of cereal cell wall components with Congo Red and Calcofluor. Specific detection and histochemistry of $(1 \rightarrow 3),(1 \rightarrow 4)-\beta-D$ glucan. Journal of Cereal Science 1: 95-110.

Zhang, D., Moore, W.R. \& Doehlert, D.C. 1998. Effects of oat grain hydrothermal treatments on wheat-oat flour dough properties and breadbaking quality. Cereal Chemistry 75: 602-605.

\title{
SELOSTUS
}

\section{Taikinaan lisättyjen gluteenin ja transglutaminaasin vaikutus kauraleivän rakenteeseen}

\author{
Marjatta Salmenkallio-Marttila, Katariina Roininen, Karin Autio ja Liisa Lähteenmäki \\ VTT Biotekniikka
}

Tässä tutkimuksessa verrattiin taikinaan lisättyjen gluteenin ja transglutaminaasin vaikutusta kauraleivän mikrorakenteeseen, rakenteeseen ja aistittavaan rakenteeseen. Vertailulla haluttiin selvittää, miten makromolekyylien (proteiinin ja tärkkelyksen) tila vaikuttaa leivän mitattaviin ja aistittaviin rakenneominaisuuksiin. Koeleipien rakennetta mitattiin valomikroskopian, instrumentaalisen rakenneprofiilianalyysin ja kuvailevan aistinvaraisen analyysin avulla. Glutee- nin ja transglutaminaasin lisäys muutti leivän proteiiniverkon rakennetta ja veden jakautumista proteiini- ja tärkkelysfaasien välillä. Transglutaminaasin vaikutuksesta leivän sisus oli kovempi ja kumimaisempi kuin ilman lisättyä entsyymiä leivottujen leipien. Leipien mikrorakenne vaikutti selvästi niiden aistittaviin ja instrumentaalisesti mitattaviin rakenneominaisuuksiin. 